\title{
Summary of requirements for the use of cells and batteries in potentially explosive atmospheres
}

\author{
Adriana Andriș ${ }^{*}$, Marius Darie $^{1}$, Dănuț Grecea ${ }^{1}$, Sorin Burian ${ }^{1}$, and Tiberiu Csaszar ${ }^{1}$ \\ ${ }^{1}$ National Institute for Research and Development in Mine Safety and Protection to Explosion - \\ INSEMEX, 32-34 G-ral Vasile Milea Street, Petrosani, Romania
}

\begin{abstract}
The use of wireless equipment in the industrial field is a modern trend both in terms of communication equipment, monitoring of gas concentration, environment or installations but also for remote controls and power backup. The energy source for such equipment are cells and batteries. The first part of the article addresses the risk of explosion and the peculiarities of flammable atmospheres. The second part was dedicated to the presentation of the types of cells suitable for use in explosive atmospheres. The last part presents a summary of the specific requirements of cells and batteries regarding the explosion protection.
\end{abstract}

\section{Introduction}

The use of wireless equipment in the industrial field is a modern trend both in terms of communication equipment, monitoring of gas concentration, environment or installations but also for remote controls.

The energy source for such equipment are cells and batteries. They can act as an uninterruptible power supply in case of interruption or failure of the main power supply or can represent the main power supply of a circuit or entire equipment (hand-held, transportable and movable equipment).

When we talk about the cells and batteries intended for use in equipment operating in explosive atmospheres, they must also comply with the safety requirements related to the risk of explosion.

\section{Explosion risk}

The explosion risk involved by the presence of technical equipment in areas endangered by the presence of flammable substances is manifested through many sources of risk. The spark ignition [1] is caused by electrical equipment, electrostatic discharges and mechanical impact. The mixtures of air with flammable substances could be ignited also, by hot surfaces [2].

\footnotetext{
*Adriana ANDRIȘ: Adriana.Andris@insemex.ro
} 
An essential element in assessing the risk of explosions in workplaces where explosive atmospheres may occur is the installations and equipment that must be designed, manufactured, installed and maintained so that they cannot generate ignition sources.

When evaluating equipment intended for use in explosive atmospheres, which contain galvanic elements and batteries, the occurrence of dangerous events such as short circuits, overheating and over-charge / over-discharge of electric currents in galvanic elements and batteries must also be taken into account [3]. These dangerous conditions may lead to exothermic chain reactions inside the storage system, which then may release toxic and/or flammable gases and finally catch fire.

This can be done from the design phase of the electrical equipment which includes galvanic elements and batteries, respecting the safety requirements related to them, mentioned in the standards specific to the applicable types of protection.

The specific types of protection applicable to equipment intended for use in explosive atmospheres are regulated by the series of standards [4-11] and compliance with these requirements leads implicitly to compliance with the requirements of ATEx Directive [12].

\section{Types of explosion protection}

The types of explosion protection are implemented by using specific requirements from relevant standards. Those requirements are applied to electric equipment in order to prevent ignition of explosive surrounding atmosphere.

Depending on the technical solution used, the standardized types of protection that can be applied to equipment intended for use in explosive atmospheres can be grouped as follows:

a) insulation of electrical equipment or parts thereof likely to cause ignition of explosive atmospheres in the hazardous area:

- encapsulation " $m$ " - avoid ignition of a layer of dust or an explosive atmosphere by completely enclosing in a compound the parts capable of igniting an explosive atmosphere, either by sparks or by heating;

- $\quad$ pressurized enclosure " $p "$ - enclosure in which a protective gas is maintained at a pressure greater than that of the external atmosphere;

- powder filling "q" - the parts capable of igniting an explosive gas atmosphere are fixed in position and completely surrounded by filling material to prevent the ignition of an external explosive gas atmosphere;

b) removal of the ignition source:

- increased safety "e" - additional measures are applied so as to give increased security against the possibility of excessive temperatures and against the occurrence of arcs and sparks;

- $\quad$ type of protection " $n$ "- in normal operation and in certain specified regular expected occurrences, electrical equipment is not capable of igniting a surrounding explosive gas atmosphere;

c) preventing the propagation of ignition throughout the mixture from external hazardous area:

- $\quad$ flameproof enclosures "d" - the parts which can ignite an explosive gas atmosphere are placed into enclosure which can withstand the pressure developed during an internal explosion of an explosive mixture, and which prevents the transmission of the explosion to the explosive gas atmosphere surrounding the enclosure;

d) limiting energy in circuits that can be a source of ignition:

- intrinsic safety "i" - restriction of electrical energy within equipment and of interconnecting wiring exposed to the explosive atmosphere to a level below that which can cause ignition by either sparking or heating effects. 


\section{Types of cells suitable for use in explosive atmospheres}

The types of cells (standardized electrochemical systems) permitted for use in explosionprotected equipment by the types of protection specified above are mentioned in the general requirements standard for equipment used in explosive atmospheres.

These cells are classified according to the possibility of being loaded in two categories:

- $\quad$ primary - those that are not designed to be electrically recharged;

- $\quad$ secondary - those that are designed to be electrically recharged.

Another classification of cells is based on the possibility of releasing gas or liquid from the inside during normal operation. From this point of view there are:

- $\quad$ sealed cells - those that remains closed and does not release either gas or liquid when operated within the limits specified by the manufacturer;

- $\quad$ valve-regulated cells - those that are closed under normal conditions but which has an arrangement which allows the escape of gas if the internal pressure exceeds a predetermined value;

- $\quad$ vented cells - those that have a cover provided with an opening through which products of electrolysis and evaporation are allowed to escape freely from the cell or battery to the atmosphere

\section{Requirements for cells and batteries used in explosive atmospheres}

Batteries intended for use in explosion-proof equipment should be connected in series only, unless the standard for the specific type of protection applied to the equipment states that their connection in parallel is also accepted. The parallel connection of the cells that form a battery is allowed only by the protection types "e" ("ec") and "i".

Cells that form a battery should have the same electrochemical system, the same design and nominal capacity, and must be made by the same manufacturer.

The construction and placement of cells should be carried out in such a way as to prevent electrolyte leakage.

Equipment containing cells and replaceable batteries should have marked on the housing or inside it, the relevant parameters thereof.

The replaceable battery pack of the explosion-proof equipment may be located either inside or outside the equipment housing, but in this case the disconnection from the equipment must be carried out in a safe area. Replacement of cells, batteries or battery packs may also be performed in the explosion hazard area if the standard for the type of protection applied to the equipment allows it.

In addition, the types of explosion protection stipulate requirements for the prevention of hydrogen leakage inside equipment and corrosive substances that have as their source the electrolyte of hazardous overheating, internal short circuits and the prevention of charging from other power sources.

Table 1 summarizes the requirements imposed by the specific standards of the types of protection divided by the construction type of the cells and by the discharging or charging operation stage.

Table 1. Synthesis of specific requirements for various construction types of galvanic elements

\begin{tabular}{|c|c|c|c|c|c|c|c|c|}
\hline & $\begin{array}{c}\text { Equipment } \\
\text { with type of } \\
\text { protection } \\
\text { "d" }\end{array}$ & $\begin{array}{c}\text { Equipment } \\
\text { with type of } \\
\text { protection } \\
\text { "e" }\end{array}$ & $\begin{array}{c}\text { Equipment } \\
\text { with type of } \\
\text { protection } \\
\text { "i" }\end{array}$ & $\begin{array}{c}\text { Equipment } \\
\text { with type of } \\
\text { protection } \\
\text { "p" }\end{array}$ & $\begin{array}{c}\text { Equipment } \\
\text { with type of } \\
\text { protection } \\
\text { "m" }\end{array}$ & $\begin{array}{c}\text { Equipment } \\
\text { with type of } \\
\text { protection } \\
\text { "n" }\end{array}$ & $\begin{array}{c}\text { Equipment } \\
\text { with type of } \\
\text { protection } \\
\text { "q" }\end{array}$ \\
\hline $\begin{array}{c}\text { Sealed } \\
\text { cells }\end{array}$ & discharging & & $\leq 25 \mathrm{Ah}$ & & & & "ec" & $\leq 25 \mathrm{Ah} ;$ \\
\hline
\end{tabular}




\begin{tabular}{|c|c|c|c|c|c|c|c|c|}
\hline & charging & + & + & + & + & + & + & + \\
\hline $\begin{array}{c}\text { Valve- } \\
\text { regulated } \\
\text { cells }\end{array}$ & discharging & + & + & & & $\otimes$ & $\otimes$ & + \\
\cline { 2 - 9 } & charging & $\otimes$ & $\otimes$ & + & + & $\otimes$ & $\otimes$ & + \\
\hline $\begin{array}{c}\text { Vented } \\
\text { cells }\end{array}$ & discharging & $\otimes$ & + & $\otimes$ & 0 & $\otimes$ & $\otimes$ & + \\
\cline { 2 - 9 } & charging & $\otimes$ & $\otimes$ & $\otimes$ & 0 & $\otimes$ & $\otimes$ & + \\
\hline $\begin{array}{c}\text { Encapsulated cells } \\
\text { (enclosed in a } \\
\text { compound) }\end{array}$ & 0 & + & & & 0 & 0 & 0 \\
\hline $\begin{array}{c}\text { Inherently Safe (IhS) } \\
\text { cells }\end{array}$ & 0 & $\leq 25 \mathrm{Ah}$ & 0 & & 0 & 0 & 0 \\
\hline
\end{tabular}

Key

Accepted without additional conditions

Accepted with additional conditions

Not accepted

0 There are no requirements in the specific standard to the type of protection of the equipment

After counting the conditions imposed by the relevant standards of the types of protection for the use of cells, separately for the using aspects and separately for the constructive aspects of cells and batteries in electrical equipment, the diagram in figure 1 resulted.

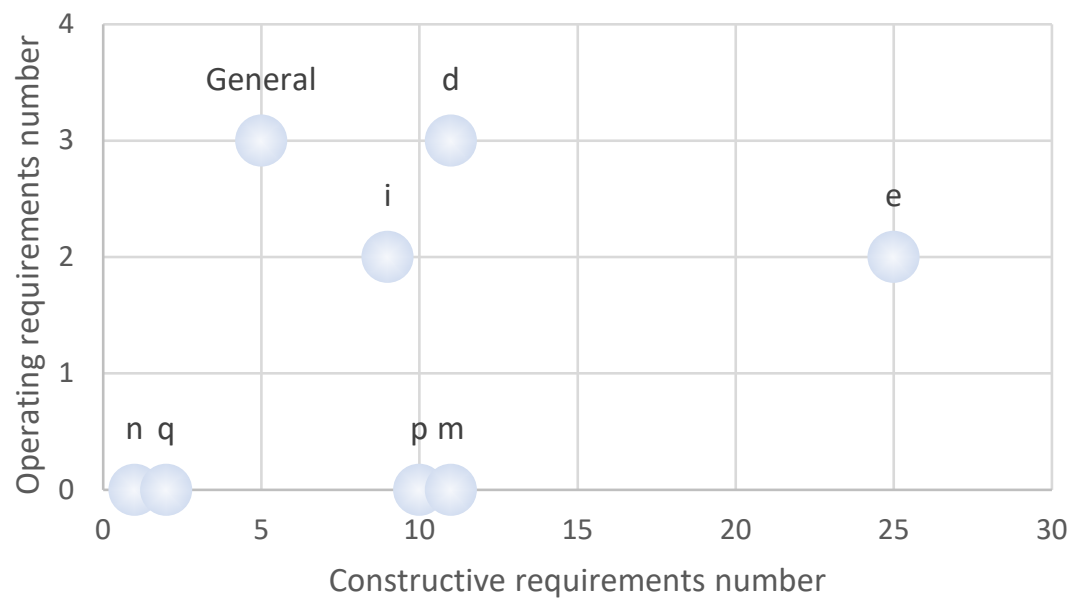

Fig. 1. Number of specific requirements mentioned by the types of explosion protection

\section{Conclusions}

Aspects of the risk of explosion when using cells and batteries in electrical equipment used in areas where flammable substances may be released have been highlighted.

The specific requirements according to the explosion protection standards of the types of protection have been summarized. 
The conditions imposed by the standards in force regarding the explosion protection were analyzed according to the constructive type of the cells, highlighting separately the discharging and charging stages.

Also, the number of requirements specific to each type of explosion protection was highlighted graphically for both the using aspects and constructive aspects of cells and batteries.

The analysis of the syntheses performed showed that the sealed cells have maximum acceptability for the discharge stage for all types of explosion protection.

These are followed by the encapsulated cells and the Inherently Safe (IhS) cells.

Another aspect of novelty highlighted was the fact that the type of protection " $n$ " and powder filling type of protection have the least requirements regarding the use of cells. Also, the pressurized enclosure type of protection and encapsulation type of protection does not present specific conditions regarding the use of cells and batteries.

The increased safety type of protection and intrinsic safety type of protection provide a similar number of conditions imposed for the use of cells.

The flameproof enclosure type of protection provides the most conditions on the use side of galvanic elements and the type of protection increased safety provides the most conditions on the construction side of cells and batteries in electrical equipment intended for use in explosive atmospheres.

\section{References}

1. M. Darie, J. Ionescu, S. Burian, T. Csaszar, L. Moldovan, Envir Eng Manag Jour 11 (5), (2012)

2. L. Moldovan, S. Burian, M. Magyari, M. Darie, D. Fotau, Envir Eng Manag Jour 16 (6), (2017)

3. T. Csaszar, S. Burian, M. Darie, C. Colda, A. Andris, Proceedings of the 7th International Multidisciplinary Symposium UNIVERSITARIA SIMPRO 1, 339-344 (2016)

4. Standard SR EN IEC 60079-0 (2018)

5. Standard SR EN 60079-1 (2015)

6. Standard SR EN 60079-2 (2015)

7. Standard SR EN 60079-5 (2015)

8. Standard SR EN 60079-7 (2016)

9. Standard SR EN 60079-11 (2012)

10. Standard SR EN IEC 60079-15 (2019)

11. Standard SR EN 60079-18 (2015)

12. Directive 2014/34/EU (2014) 